Medical Legal PRoblems

\title{
A proposal for limited criminal liability in high-accuracy endoscopic sinus surgery
}

\author{
Una proposta di ridotta responsabilità penale nella chirurgia endoscopica sinusale \\ P. VOULTSOS'1, M. CASINI², G. RICCl ${ }^{3}$, V. TAMBONE4, E. MIDOLO², A.G. SPAGNOLO2 \\ ${ }^{1}$ Laboratory of Forensic Medicine \& Toxicology, School of Medicine, Aristotle University of Thessaloniki, Greece; \\ ${ }^{2}$ Institute of Bioethics \& Medical Humanities, School of Medicine, Università Cattolica del Sacro Cuore, Rome, \\ Italy; ${ }^{3}$ School of Law, University of Camerino, Italy; ${ }^{4}$ Institute of Philosophy of Scientific and Technological Activity, \\ Campus Bio-Medico University of Rome, Italy
}

\section{SUMMARY}

The aim of the present study is to propose legal reform limiting surgeons' criminal liability in high-accuracy and high-risk surgery such as endoscopic sinus surgery (ESS). The study includes a review of the medical literature, focusing on identifying and examining reasons why ESS carries a very high risk of serious complications related to inaccurate surgical manoeuvers and reviewing British and Italian legal theory and case-law on medical negligence, especially with regard to Italian Law 189/2012 (so called "Balduzzi" Law). It was found that serious complications due to inaccurate surgical manoeuvers may occur in ESS regardless of the skill, experience and prudence/diligence of the surgeon. Subjectivity should be essential to medical negligence, especially regarding high-accuracy surgery. Italian Law 189/2012 represents a good basis for the limitation of criminal liability resulting from inaccurate manoeuvres in high-accuracy surgery such as ESS. It is concluded that ESS surgeons should be relieved of criminal liability in cases of simple/ordinary negligence where guidelines have been observed.

KEY WORDS: Endoscopic sinus surgery • Malpractice • Medical liability • Gross negligence • Italian Law 189/2012

\section{RIASSUNTO}

Lo studio ha lo scopo di sollecitare una riforma della responsabilità penale che preveda una riduzione di responsabilità legale per la chirurgia ad alta precisione, per quella ad alto rischio, come per esempio la chirurgia endoscopica sinusale (ESS). Il contributo comprende una revisione della letteratura medica, concentrandosi sull'identificazione e sull'esame dei motivi per cui la tecnica di ESS corre un rischio molto elevato di produrre gravi complicazioni dovute a manovre chirurgiche inesatte. Tale contributo, prevede anche una revisione della teoria del diritto e della giurisprudenza britannica e italiana in merito alla negligenza medica, soprattutto con riferimento alla L. italiana n. 189 del 2012 ("Decreto Balduzzi"). Si è constatato che gravi complicanze dovute a manovre chirurgiche non corrette di ESS possono verificarsi, indipendentemente dalla prudenza/diligenza del chirurgo. La soggettività in termini giuridici risulta essenziale per la negligenza medica, soprattutto con riferimento alla chirurgia ad alta precisione. La legge italiana 189/2012 rappresenta una buona base per la limitazione della responsabilità penale derivante da manovre imprecise in chirurgia ad alta precisione, come appunto l'ESS. In conclusione, si considera che $i$ chirurghi che eseguono ESS dovrebbero essere esonerati da responsabilità penale in caso di negligenza lieve sopravvenuta nonostante il rispetto delle line guida emanate.

PAROLE CHIAVE: Chirurgia sinusale endoscopica $\bullet$ Negligenza $\bullet$ Responsabilità medica $\bullet$ Lieve negligenza/grave negligenza $\bullet$ Legge Italiana N. 189/2012 ("Decreto Balduzzi")

Acta Otorhinolaryngol Ital 2017;37:65-71

\section{Introduction}

Functional endoscopic sinus surgery (ESS) has been developed over the last 20 years ${ }^{1}$ and is being adopted more commonly. A US study for the period 1985-2005 reports that $70 \%$ of malpractice claims in ENT referred to rhinology, and most involved ESS ${ }^{2}{ }^{3}$. This is due to the fact that modern techniques (i.e. FESS) involve penetration into inaccessible areas and deal with conditions including chronic or recurrent rhinosinusitis (CRS) ${ }^{3}$ and polyposis (in $73 \%$ and $12 \%$ of cases, respectively) ${ }^{4}$. The aim of ESS is to restore the physiology of the nasal mucosa ${ }^{5}$. FESS has high success rates $(\sim 90 \%)^{6}$, but widespread use of such methods results in an increase in potential complications. While refinement of these methods reduces complications, it cannot eliminate them ${ }^{3}$.

Given that during ESS a marginally negligent manoeuvre may cause serious injury and complications, it is one of the techniques most vulnerable to malpractice litigation. The $76 \%$ of ESS-related malpractice litigation refers to negligence ${ }^{4}$. Common serious injuries caused by FESS include: CSF leak and diplopia (24\% and $17 \%$, respectively, according to one study), blindness, intracranial brain injury, life-threatening haemorrhage and nerve injuries ${ }^{47}$. 


\section{Endoscopic sinus surgery: very high-accuracy (high-risk) surgery}

ESS is a high-accuracy (high-risk) form of surgery. The risk of error depends largely on the patient's characteristics, i.e. on the "specific bio-individual reactions" or the so-called 'endogenous risks' (anatomical variations, type of disease, individual reactions, co-morbidities and medications), rather than on 'exogenous risks' (including type of method chosen, type of instruments, type of anaesthesia administered, positioning of the patient, skill and experience of the surgeon) ${ }^{7}$. The risk of error during a medical (surgical) procedure can be reduced (or minimised) with a thorough preoperative evaluation of individual anatomical variations using CT scan in axial, coronal and parasagittal planes ${ }^{178}$, the use of image guidance (IG) surgery ${ }^{79}$ and limiting the possibility of excessive intraoperative bleeding (using reverse Trendelenburg body positioning, maintaining low arterial blood pressure etc.) ${ }^{10}$. However, such risks cannot be completely eliminated ${ }^{311}$. Endoscopic sinus surgery is performed on anatomical regions featuring close proximity of anatomical structures, including nerves (e.g. optic nerve), skull-base, dura mater, blood vessels (e.g. internal carotid artery), orbit, lachrymal duct, etc. The position of anatomical structures, both individually and in relation to each other, may vary, the thickness of a bone covering vessels and nerves may be minimal, or there may be some dehiscence. Some vessels or nerves crossing a cavity (e.g. pneumatised sphenoid sinus, SS) may be in a mesentery position.

\section{The extremely high-risk surgical field of ESS}

The narrow, complex and inaccessible nature, and relative limited visibility, of the operative field of ESS, in addition to the probability of individual anatomical variations (congenital or subsequent), together with the close proximity of critical anatomical structures, often make serious complications inevitable, even for the most skilled and experienced surgeon familiar with endoscopic anatomy and the use of instrumentation, especially during FESS or ETTS (Endoscopic Transnasal Transsphenoidal Surgery) and in the case of revision surgery. The operative field may become more restricted and more obscure (poor) whenever anatomy is distorted in some regions (e.g. in revision surgery with potential scarring, syndromes including Kartagener syndrome, cystic fibrosis, connective tissue disorders, diffuse polyposis with connective tissue growth etc. ${ }^{7}$. The common causes of an obscure operative field include polyposis or intraoperative bleeding, especially during revision surgery ${ }^{311}$, which predisposes intervention to major complications, although this has been disputed recently ${ }^{12}$. Thus, a surgeon may be denied the possibility of visualising some well-known anatomical (surgical) landmarks that gen- erally facilitates surgery, including the maxillary sinus ostium ${ }^{13}$, the intact middle turbinate for identifying the maxillary sinus ostium ${ }^{13}$, the point of contact between the third nerve and the tentorial edge for protecting the fourth nerve from an erroneous surgical procedure during skull-base surgery ${ }^{14}$, and the inferior turbinate and vertical middle turbinate attachment that guide the extent of cartilage incision during ESS ${ }^{15}$.

A well-known complication of ESS, rare $(\leq 1 \%)$ though serious, is skull-base injury ${ }^{16}$. The most common cause of iatrogenic skull-base injury is ESS, during which an injury to the ethmoid roof and lateral lamella of the cribriform plate occurs intraoperatively, resulting in an iatrogenic cerebrospinal fluid leak (CSF leak) ${ }^{17}$. CSF leak may occur even during surgery by the most skilled hands. The anatomical variations in skull-base anatomy, the complexity of the case (e.g. in revision surgery) and a surgeon's inadequate experience and familiarity with the method used, may function as risk factors for CSF leak ${ }^{18}$. Good preoperative testing and planning may reduce the possibility of CSF leak to a considerable degree. Anatomical elements predisposing a patient to a CSF leak due to FESS include a "steep skull-base angle at the sagittal plane, a greater slope of the skull base at the coronal plane and a low cribriform height relative to the ethmoid roof" ${ }^{19}$. A preoperative review of imaging in terms of these particular anatomical variations is recommended, along with adoption of the Keros classification, which is used to describe the ethmoid skull-base configuration/ height and helps physicians avoid iatrogenic injury to the cribriform region and medial ethmoid roof ${ }^{20}$. The osseous lamina at the ethmoid roof is extremely thin $(0.05 \mathrm{~mm}$ at the frontal bone), the lateral lamella of the cribriform plate is $0.2 \mathrm{~mm}$ thick on average and the ethmoidal sulcus is $0.05 \mathrm{~mm}$ thick on average ${ }^{21}$. Thus, they are vulnerable to the surgical manoeuvres of ESS (high risk of perforation or split). Evaluation of the ethmoid skull-base height is important to avoid any complications during surgery ${ }^{22}$. A low-lying skull base is risky: the ethmoid skull base (ESB) extends from the superior attachment of the cribriform plate's lateral lamella to the junction of the lamina papyracea, and varies between $3.7 \mathrm{~mm}$ and $15.4 \mathrm{~mm}$ in thickness ${ }^{23}$.

The upper medial border of FESS is determined by lamina papyracea (LP) and lamina cribrosa and its lateral lamella (the deeper the former the thinner the latter), while the upper lateral border is the anterior ethmoidal artery (AEA). LP may be in an excessively medialised position relative to the lateral nasal wall, thus rendering orbital penetration more likely ${ }^{24}$. Attachment of the uncinate process to LP is a high-risk variation (similar to the lateral surface of the middle turbinate or the anterior skull base) ${ }^{8}$. LP is tested for dehiscence or orbital fat protrusion into the ethmoid sinus or maxillary sinus (at a rate of $0.5-10 \%$ ) ${ }^{25}$. When the olfactory fossa is deep, depending on the angle 
formed by the lateral and perpendicular walls, then the risk of skull-base injury increases ${ }^{26}$.

In (F)ESS, any anatomical variations of the most variable cavity of the human body, i.e. the SS, must be evaluated before surgery ${ }^{1}$. Pneumatisation (of conchal, presellar, or sellar type) of the SS varies greatly among individuals, and also varies according to age, gender, and race ${ }^{27}$. It may extend to the (anterior) clinoid process (in 6-17\% of cases) ${ }^{1}$, which is dangerous. Pneumatisation may be present at the pterygoid process $(25-57 \%)$, carotid, optic nerve, Vidian canal, foramen rotundum and greater wing ${ }^{1}$. Optic nerve dehiscence is reported in $6 \%$ and prominence in $40 \%$ of patients ${ }^{28}$. Given that asymmetry is also reported at the ethmoid (>2 $\mathrm{mm}$ in $8 \%$ of patients) ${ }^{29}$, it is possible that the surgeon may misinterpret the patient's anatomy and believe he/she is at the posterior ethmoid, while he/she is in fact at the SS.

In $3-42 \%$ of patients ${ }^{7}$, a so-called (sphenoethmoid) "Onodi cell" is found; this is a posterior ethmoid cell pneumatising into the superolateral aspect of the SS ${ }^{17}$. It represents a risk for the ESS surgeon, since it is very close to the optic nerve, internal carotid artery and sellar floor, and associated with dehiscence of the optic nerve and internal carotid artery ${ }^{30}$. Dehiscence of the carotid canal, optic canal, foramen rotundum etc. leads to a high risk of serious complications. Such dehiscence is reported in $4-25 \%$ of patients ${ }^{1}$.

The occurrence of accessory bony septa or crests, as well as the occurrence of bony intramaxillary sinus septa in the SS (or in the optic or Vidian canal), also represents a risk for the surgeon ${ }^{18}$. $91 \%$ of AEAs (Anterior Ethmoidal Arteries) "are located within the skull base or 1-2 mm below, while $9 \%$ are suspended in a mesentery hanging" ${ }^{7}$. The artery may be $5 \mathrm{~mm}$ from the skull base (which is a highly risky variation). A high rate of AEAs (up to $43 \%$ according to a study) move freely within the ethmoid cells ${ }^{8}$. Aggressive disease removal and removal of SS septa attached to the bone just forward of the carotid artery may result in its injury.

The carotid artery aims at the lateral wall of the SS at a rate of $71-98 \%{ }^{7}$. In $88 \%$ of cases, the bone that covers the artery is $<5 \mathrm{~mm}^{\text {thick }}{ }^{7}$. In $4-22 \%$ of cases, it is dehiscent (up to grossly dehiscent) ${ }^{7}$. Accordingly, as the internal carotid artery and the optic nerve cross the Onodi cell, they may be dehiscent (4-8\%), covered by a thin sinonasal layer, while in $78 \%$ of cases, they are covered by a thin layer of bone $(<5 \mathrm{~mm} \text { thick })^{31}$. If the anterior clinoid of the SS is pneumatised, then the optic nerve or the AEA may be in mesentery hanging across the roof of the sphenoid ${ }^{26}$ (which is highly dangerous). Basak et al. note that an extreme medial location of the carotid canal and the bulging of the optic canal into the sphenoid sinus are very dangerous ${ }^{8}$.

Often the optic nerve or the carotid artery is very highly susceptible to injuries due to these anatomical variations, or even due to minimal surgical manipulation.
Measurement, identification and evaluation of anatomical structures, and accuracy of these techniques

Preoperatively, a high-definition multi-slice helical CT scan of sinuses must be performed (following maximal medical therapy), principally in the axial, coronal and parasagittal planes (slices between $0.5 \mathrm{~mm}$ and $1 \mathrm{~mm}$ ) ${ }^{17830}$. Even the most minute anatomical variations can be detected with utmost accuracy ${ }^{32}$. CT is mandatory before ESS, insofar as the safety of ESS "depends on a surgeon's knowledge and experience to a great extent" ${ }^{30}$. According to one study, however, a CT scan can hardly evaluate whether there is any dehiscence of the optic nerve or of the carotid artery (or both) as they cross the SS ${ }^{1}$.

During surgery, the surgeon is often assisted by image guidance (IG) systems; however, such systems are unable to assess the sinus and skull-base anatomy accurately, due to the so-called "target recognition error" (TRE) in terms of the location of the corresponding targets on CT ( $2 \mathrm{~mm}$, approximately) ${ }^{33}{ }^{34}$. During the use of image guidance technology there may be some discrepancy between anatomic endoscopic visualisation and the computer image. It is reported that "the skull base or the orbit should be given at least 2-3 $\mathrm{mm}$ as a buffer safety zone". TRE is a statistical distribution, and for each point in the image, the TRE may be different. "It is rare to remove the disease right to the skull base or orbit using computer guidance" ${ }^{35}$. It has been argued that "not using IG does not necessarily make one more vulnerable to malpractice litigation" ${ }^{9}$.

\section{Instruments used and risks resulting from their use.}

Spatial orientation disorders among surgeons

The type of instruments used may lead to an increased risk of medical error, e.g. the use of angled endoscopes and instruments makes surgical error more likely for a right-handed surgeon when the lesion is on the right side (and for a left-handed surgeon when the lesion is on the left side) ${ }^{3735}$. When the instrument is at a relatively parallel position to the ethmoid roof during ESS surgery, a surgeon may have a distorted perception of orientation ${ }^{7}$. Stankiewicz notes that "during ESS, a right-handed surgeon has to deal with an anatomic illusion on the left side. The left ethmoid sinuses are actually more medial than appreciated by a right-handed surgeon" 35 .

Power instruments increase the possibility of error, and more specifically of the severity of complications (since they exert a cutting and suction action), mostly due to penetration into the endocranium and the orbit. If the lamina papyracea is injured, it may be sucked to orbital fat resulting in injury of the rectus muscle and diplopia ${ }^{7}$, especially if there is injury at the third posterior of the lamina papyracea, where there is less fat between the papyracea and the muscle. It is not clear whether the balloon catheter systems used to dilate the sinus ostia are at least equally safe as other ESS techniques ${ }^{73637}$. 
Risks due to anaesthesia or to physicians

(surgeons or anaesthesiologists)

A surgical procedure may cause injury because general anaesthesia reduces the sensitivity of anatomical structures (patient feedback) when the ESS surgeon approaches sensitive structures such as the lamina papyracea and the skull base or the orbit ${ }^{335}$. Thus, the surgeon may penetrate very risky anatomical regions unhindered. Furthermore, in case of minimal movement by the patient, the ESS surgeon may find him/herself involved in medical litigation without any negligence on his/her part ${ }^{38}$.

\section{Even the most skilled and experienced surgeons are "at risk"}

In ESS it is very possible that a surgeon will follow the guidelines and still be found guilty, despite the fact that his/her negligence was ordinary and possibly inadvertent, or that there was no deviation from his/her standard of care. Complications are uncommon but very serious, and depend highly on the patient's characteristics. The physician's experience is fundamental in reducing them, but cannot eliminate them altogether. Complications are possible even for the most skilful and experienced surgeons 3535 39. A minimal surgical manipulation (e.g. a marginally negligent manoeuvre) may result in serious iatrogenic injury.

Legal action may easily lead to finding a physician guilty whenever there is a complication. "The occurrence of a complication puts a surgeon at risk, even if he or she was not at fault". "The severity of the patient's disability, rather than the occurrence of an adverse event due to negligence, was predictive of payment to the plaintiff". "The standard of medical litigation performs poorly in malpractice litigation" ${ }^{40}$. A surgical error may be committed entirely unwittingly instead of negligently, for example it is not easy for surgeons "to know for themselves how much force they are exerting as they handle surgical tools" ${ }^{41}$.

\section{Italian Law No. 189/2012 ("Balduzzi" Law): a reform to restrict medical malpractice litigation}

In Italy, Article 3 of Law No. 189/8.11.2012, which amended Decree-Law No. 158/2012 and entered into force on 11.11.2012, provides for the decriminalisation of simple/ordinary negligence (culpa levis) of a physician provided that he/she followed the guidelines and "good medical practice" accredited by the scientific community while carrying out his/her activities ${ }^{42}$. It may be of some concern that the original version of Art. 3 contained in Decree 158/2012 was slightly different from the latest version contained in Law 189/2012. Indeed, the original version stated that: "Withstanding the provisions of Article 2236 of the Civil Code, the Judge - pursuant to Article
1176 of the Civil Code - in the assessment of negligence in the health workers' activity, shall take into account in particular the observance, in the concrete case, of guidelines and good practices accredited by the national and international scientific community".

Successively, Art. 3 of Law 189 was changed to the following: "Health workers who in carrying out their activities adhere to guidelines and good practices accredited by the scientific community are not liable for criminal negligence. In such cases there is no prejudice of Article 2043 of the Civil Code. The judge, when determining damages, shall also take due account of conduct in accordance with the first paragraph".

It is clear that in updated Art. 3 there is an explicit reduction of liability in the criminal field, to culpa levis. In other words, Italian legislation introduced a partial abolition criminis. Such a limitation of the physician's criminal liability is not extended to civil liability. However, in determining injuries to the patient, the judge has to consider that the physician followed the provisions of the guidelines and nevertheless caused injury to the patient (third sentence of Article 3, 1st Subsection of Italian Law 189/2012) ${ }^{43}$.

The distinction between ordinary and gross negligence (culpa lata) determines not only the quantum, but also the an respondeatur. Therefore, a sharp discrimen is a requirement for not violating the important principle of criminal law nullum crimen nulla poena sine lege. Gross negligence implies an unjustifiable degree of negligence from an objective point of view ${ }^{3844}$. Such legislation leads to a limitation of "defensive medical practice", favouring a good relationship between physician and patient, patient safety and quality healthcare.

\section{Guidelines and constitutionality of the Law}

There are several reasons, for example those involving financial issues and the protection of legal rights, for the establishment of guidelines which can play a role in limiting criminal cases ${ }^{45}$. Guidelines need to be "indisputable" if they are to attain such a decriminalising role. However, they have no clear legal force; as a result, the absolute value of the guidelines has been disputed by the Italian Court of Cassation ${ }^{46}$.

Furthermore, adherence to guidelines would render medical liability objective ${ }^{47}$. The assessment of medical liability is by its very nature subjective. A physician is under an obligation to provide the means, and not to obtain a result. However, in recent years there has been a tendency to "objectify" medical liability (in countries such as Greece ${ }^{47}$, Italy ${ }^{48}$ and Portugal ${ }^{49}$ ).

It is possible that the patient's interest in a particular case is better served by a deviation from the guidelines, rather than adherence to them ${ }^{50}$. Non-adherence to these guidelines is not indicative of negligence, and on the contrary, adherence to them does not result in an "automatic de- 
fence of negligence" ${ }^{51}$. It seems that the application of guidelines protects physicians in terms of criminal liability in cases of marginal negligence, which may be more easily characterised as ordinary. Italian legislation implies that the guidelines resemble a navigation chart: if a surgeon follows them, s/he can only be held responsible for hitting the visible shelf. If s/he does not follow them, s/he can also be held responsible for hitting the reef ${ }^{52}$.

Law No. 189/2012 has been discussed because of different interpretations in both Italian courts ${ }^{53}$ and the legal literature ${ }^{54}$. It has been said that "from an analysis of case law, it is possible to conclude that there is interpretative doubt about the field of application of this reform. At the moment, the Supreme Court has taken a clear position, but this does not exclude potential future action by legislators" ${ }^{55}$. Moreover, Law No. 189/2012 was interpreted by the Italian Supreme Court of Cassation ${ }^{56}$ and also by the Italian Constitutional Court ${ }^{57}$.

To conclude, we believe that the legislative change introduced by Article 3 of Italian Law 189/2012 is a fundamental step towards ensuring the smooth-running of both the provision of healthcare services and administration of justice in the courts.

\section{Advertent and inadvertent medical negligence}

Gross negligence is usually based on advertent negligence (recklessness), as being an expression of a highly antisocial attitude. Gross negligence involves extreme carelessness or incompetence, which is expressed, however, through some serious form of negligent conduct (unjustifiable risk taking) ${ }^{58}$. Liability depends on foresight, on the conscientious taking of an unjustified risk. Utilitarians put social needs above individual needs, and advocate punishment in order to protect the community, since subjectivists are unable to make a clear distinction between knowledge and awareness of a risk ${ }^{58}$. In this paper, we stand with subjectivists regarding liability for inaccurate manoeuvres in high-accuracy surgery. In our opinion, an external distinction between gross and simple negligence roughly corresponds to an internal distinction between advertent and inadvertent negligence. This position, although we refer to "roughly corresponding", is not in contrast with the principle nullum crimen nulla poena sine lege, because it is maintained (in British legal theory) that the distinction between recklessness and gross negligence is subtle (they are almost identical) ${ }^{59}$, although recklessness is based on advertence, while gross negligence is based on the violation of a duty-of-care rule ${ }^{60}$. If the distinction between culpa levis and culpa lata (simple/ordinary and gross negligence) can hardly determine the an respondeatur (and not the quantum respondeatur), this is even more true for the distinction between inadvertent and advertent negligence (recklessness).

As medical liability tends to be "objectified", the possibility of determining an respondeatur through the distinction be- tween advertent and inadvertent negligence is invalidated. However, this should not be the case as far as high-accuracy surgical manoeuvres, where subjectivity has a crucial role, are concerned. The risk of certain surgical errors is particularly high and, in some cases, it is independent of the skill, experience and even prudence/diligence of the surgeon. Therefore, in ESS-related malpractice litigation the "objectification" of medical liability seems to be completely unjustified. During this type of surgery, a serious complication (result) may occur independently of the skill, experience and even prudence/diligence of the surgeon.

\section{Conclusion - Proposal}

Given that the guidelines acquired a crucial role, we consider - from a legal point of view - with great emphasis on subjectivity, and propose that a surgeon shall only be held criminally liable for gross negligence. Subjectivity is essential to medical negligence, especially when dealing with high-accuracy surgical procedures such as ESS. A good "tool" to ascertain not only the an respondeatur, but also the quantum respondeatur, is the judgment as to whether this constitutes negligence, because reference is made to subjectivity. An ESS surgeon should have received special and well-established training before performing surgical procedures. In our view, the attachment of a great deal of importance to subjectivity counterbalances the "objectification" of medical liability resulting from adherence to guidelines.

\section{References}

Kazkayasi M, Karadeniz Y, Arikan OK. Anatomic variations of the sphenoid sinus on computed tomography. Rhinology 2005;43:109-14.

2 Dawson DE, Kraus EM. Medical malpractice and rhinology. Am J Rhinol 2007;21:584-90.

3 Tewfik MA, Wormald PJ. Ten pearls for safe endoscopic sinus surgery. Otolaryngol Clin North Am 2010;43:933-44.

4 Lynn-Macrae AG, Lynn-Macrae RA, Emani J, et al. Medicolegal analysis of injury during endoscopic sinus surgery. Laryngoscope 2004;114:1492-5.

5 Cohen NA, Kennedy DW. Revision endoscopic sinus surgery. Otolaryngol Clin North Am 2006;39:417-35.

6 Senior BA, Kennedy DW, Tanabodee J, et al. Long-term results of functional endoscopic sinus surgery. Laryngoscope 1998;108:151-7.

7 Re M, Magliulo G, Romeo R, et al. Risks and medico-legal aspects of endoscopic sinus surgery: a review. Eur Arch Otorhinolaryngol 2014;271:2103-17.

8 Başak S, Karaman CZ, Akdilli A, et al. Evaluation of some important anatomical variations and dangerous areas of the paranasal sinuses by CT for safer endonasal surgery. Rhinology 1998;36:162-7.

9 Eloy JA, Svider PF, D'Aguillo CM, et al. Image-guidance in endoscopic sinus surgery: is it associated with decreased medicolegal liability? Int Forum Allergy Rhinol 2013;3:980-5. 
10 Drozdowski A, Sieśkiewicz A, Siemiatkowski A. Reduction of intraoperative bleeding during functional endoscopic sinus surgery. Anestezjol Intens Ter 2011;43:45-50. [Article in Polish].

11 Stankiewicz JA, Lal D, Connor M, et al. Complications in endoscopic sinus surgery for chronic rhinosinusitis: a 25-year experience. Laryngoscope 2011;121:2684-701.

12 Krings JG, Kallogjeri D, Wineland A, et al. Complications of primary and revision functional endoscopic sinus surgery for chronic rhinosinusitis. Laryngoscope 2014;124:838-45.

13 Levine HL, Clemente MP. Sinus surgery: endoscopic and microscopic approaches. N. York: Thieme Medical Publishers Inc, 2011, pp: 155-6.

14 Gupta T, Gupta SK, Sahni D. Anatomy of the tentorial segment of the trochlear nerve in reference to its preservation during surgery for skull base lesions. Surg Radiol Anat 2014;36:967-71.

15 Seth R, Haffey T, McBride JM, et al. Intranasal landmarks for adequate L-strut preservation during endoscopic septoplasty. Am J Rhinol Allergy 2014;28:265-8.

16 Gray ST, Wu AW. Pathophysiology of iatrogenic and traumatic skull base injury. Adv Otorhinolaryngol 2013;74:12-23.

17 Senior BA, Alldredge J. Endoscopic surgery of the skull base, orbits and benign sinonasal neoplasms. In: Wackym S, Snow JB (eds.). Ballenger's Otorhinolaryngology Head and Neck Surgery: Centennial Edition. Shelton: BC Decker Inc, People's medical publishing House 2009, pp. 165.

18 Grevers G. Anterior skull base trauma during endoscopic sinus surgery for nasal polyposis preferred sites for iatrogenic injuries. Rhinology 2001;39:1-4.

19 Heaton CM, Goldberg AN, Pletcher SD, et al. Sinus anatomy associated with inadvertent cerebrospinal fluid leak during functional endoscopic sinus surgery. Laryngoscope 2012;122:1446-9.

20 Ramakrishnan VR, Suh JD, Kennedy DW. Ethmoid skullbase height: a clinically relevant method of evaluation. Int Forum Allergy Rhinol 2011;1:396-400.

21 Stammberger H, Lund VJ. Anatomy of the nose and Paranasal sinuses. In: Gleeson M, Browning GG, Burton MJ (Eds.). Scott-Brown's Otorhinolaryngology, Head and Neck Surgery, Volume 1, 7th ed., London: Hodder Arnold 2008, pp. 1335.

22 Rudmik L, Smith TL. Evaluation of the ethmoid skull-base height prior to endoscopic sinus surgery: a preoperative computed tomography evaluation technique. Int Forum Allergy Rhinol 2012;2:151-4.

23 Vinay K N, Gugapriya TS, Arun TG, et al. A computerized tomographic study of height of ethmoidal skull base. Int $\mathrm{J}$ Clin Trials 2014;1:37-40.

24 Sprekelsen MB, Carrau RL. Complications in otolaryngology-head and neck surgery. New York: Thieme Medical Publishers Inc. 2013, pp: 160-70.

25 Chao T-K. Protrusion of orbital content through dehiscence of lamina papyracea mimics ethmoiditis: a case report. Otolaryngol Head Neck Surg 2003;128:433-5.

26 Wormald P-J, Tewfik MA. Preoperative work-up and assessment. In: Jones N (Ed.). Practical Rhinology. Boca Raton: CRC Press, Taylor and Francis Group, LCC 2010, pp. 48-9.
27 Tomovic S, Esmaeili A, Chan NJ, et al. High-resolution computed tomography analysis of variations of the sphenoid sinus. J Neurol Surg B 2013;74:82-90.

28 Walsh WE, Kern RC. Sinonasal anatomy, function and evaluation. In: Bailey BJ, Johnson JT, Newlands SD (Eds.). Head \& Neck Surgery - Otolaryngology. Philadelphia: Lippincott Williams \& Wilkins 2006, pp. 309.

29 Kim E, Russel PT. Prevention and management of skull base injury. Otolaryngologic Clinics of North America 2010;43:809-16.

30 Sargi ZB, Casiano RR. Surgical anatomy of the paranasal sinuses. In: Kountakis SE, Onerci TM. (Eds.). Rhinological and sleep apnea surgical techniques, 18th ed. Berlin: Springer 2007, pp. 17-26.

31 De Lano MC, Fun FY, Zinreich SJ. Relationship of the optic nerve to the posterior paranasal ainuses: a CT anatomic study. Am J Neuroradiol 1996;17:669-75.

32 Mason JDT, Jones NS, Hughes RJ, et al. A systematic approach to the interpretation of computed tomography scans prior to endoscopic sinus surgery. J Laryngol Otol 1998;112:986-90.

33 Labadie RF, Shah RJ, Harris SS, et al. In vitro assessment of image-guided otologic surgery: submillimeter accuracy within the region of the temporal bone. Otolaryngol Head Neck Surg 2005;132:435-42.

${ }^{34}$ Labadie RF, Davis BM, Fitzpatrick JM. Image-guided surgery: what is the accuracy? Curr Opin Otolaryngol Head Neck Surg 2005;13:27-31.

35 Stankiewicz JA. Complications of sinus surgery. In: Bailey BJ, Johnson JT, Newlands SD (Eds.). Head \& Neck Surgery - Otolaryngology, 4th edition. Philadelphia: Lippincott Williams \& Wilkins 2006, pp. 478-90.

36 Brown CL, Bolger WE. Safety and feasibility of balloon catheter dilation of paranasal sinus ostia: a preliminary investigation. Ann Otol Rhinol Laryngol 2006;115:293-9.

37 Stamm A, Nogueira JF, Lyra M. Feasibility of balloon dilatation in endoscopic sinus surgery simulator. Otolaryngol Head Neck Surg 2009;140:320-3.

38 Wienke A. Errors and pitfalls: briefing and accusation of medical malpractice - the second victim. GMS Curr Top Otorhinolaryngol Head Neck Surg 2013;12:Doc 10.

39 Weber R, Keerl R, Hosemann W, et al. Complications with permanent damage in endonasal paranasal sinus operations--more frequent in experienced surgeons? Laryngorhinootologie 1998;77:398-401. [Article in German]

40 Brennan TA, Sox CM, Burstin HR., Relation between negligent adverse events and the outcomes of medical-malpractice litigation. N Engl J Med 1996;335:1963-7.

41 Yamauchi Y, Yamashita J, Morikawa O, et al. Surgical skill evaluation by force data for endoscopic sinus surgery training system. In: Dohi T, Kikinis R (Eds.). Medical Image Computing and Computer-Assisted Intervention - MICCAI 2002, 5th International Conference Tokyo, Japan, September 25-28, 2002 Proceedings, Part I, Heidelberg: Springer-Verlag 2002, pp. 44-51.

42 Fiori A, Marchetti D. L'articolo 3 della legge Balduzzi $n$. 189/2012 e i vecchi e nuovi problemi della medicina legale. Rivista italiana di medicina legale 2013;2:563-72.

43 Girinelli F. Il Decreto Legge Balduzzi al vaglio della giurisprudenza: luci e ombre sulla responsabilità civile dei sani- 
tari (http://www.filodiritto.com/diritto-della-responsabilitacivile-e-del risarcimento-danni. 25 marzo 2015).

44 German Federal Court of Justice, 25-11-2011, V1 ZR 139/10.

45 Italian Court of Cassation, Criminal Section IV, 23-11-2010, n. 8254 .

46 Italian Court of Cassation, Criminal Section IV, 11-7-2012, n. 35922.

47 Psaroulis D, Voultsos P. Medical Law. Elements of Bioethics. Thessaloniki: University Studio Press 2010, pp. 231-88 [ In Greek].

48 Motta S, Nappi S. Current trends for medico-legal disputes related to functional nasal surgery in Italy. Acta Otorhinolaryngol Ital 2014;34:210-4.

49 Raposo VL, Vieira DN. Professional medical responsibility in Portugal, the juridical perspective. (In: http:// www.vda.pt/xms/files/Publicacoes/Professional_Medical_Responsibility_in_Portugal_The_Juridical_Perspective. pdf\#page=2\&zoom=auto,842,702 (last accessed 17 December 2014).

50 Civello G. Medical responsibility and compliance with the "Guidelines", between gross negligence and ordinary negligence (The new regulation of the "health decree"). Archivio Penale 2013;1:85-112. [Article in Italian].

51 Scadding GK, Durham SR, Mirakian R, et al. BSACI guidelines for the management of rhinosinusitis and nasal polyposis. Clin Exp Allergy 2008;38:260-75.

52 Piras P. Yet another no to the life jacket of ordinary negligence for the doctor who navigates off course. In: Diritto
Penale Contemporaneo (http://www.penalecontemporaneo. it/area/1-/2-/25-/3149-ennesimo_no_al_salvagente_della_ colpa_lieve_per_il_medico_che_naviga_fuori_rotta/ (last accessed 17 December 2014) [Article in Italian]

53 Among other decisions, Trib. Milano sent. n. 9693 del 23 luglio 2014 (in Foro It. 2014, 11, I, 3294); Tribunale Milano 31 gennaio.

54 Among others, Vallini A. L'art. 3, 10 comma, della legge Balduzzi: reazioni, applicazioni, interpretazioni (commento a art. 3 l. 8 novembre 2012, n. 189). Giurisprudenza Italiana 2014;8-9:2057-65.

55 Girinelli F. Il Decreto Legge Balduzzi al vaglio della giurisprudenza: luci e ombre sulla responsabilità civile dei sanitari (http://www.filodiritto.com/articoli/2015/03/il-decretolegge-balduzzi-al-vaglio-della-giurisprudenza-luci-ed-ombre-sulla-responsabilit-civile-dei-sanitari.html (last access 12 June 2016).

56 Italian Court of Cassation, Section IV, n. 11493, 11-03-2013.

57 Italian Constitutional Court, n. 295, 06-12-2013.

58 Loveless J. Complete criminal law: text, cases, and materials: text, cases, and materials. Chapter 3: Mens Rea: Intention, Recklessness, Negligence and Gross Negligence, 4th ed. Oxford: Oxford University Press 2014, pp. 91-150.

59 Merry AF. How does the law recognize and deal with medical errors? J R Soc Med 2009;102:265-71.

${ }^{60}$ Gooderham P. The distinction between gross negligence and recklessness in English criminal law. J R Soc Med 2009; 102:358.

Received: June 14, 2016 - Accepted: July 28, 2016

Address for correspondence: Emanuela Midolo, Institute of Bioethics and Medical Humanities, Università Cattolica del Sacro Cuore, School of Medicine and Surgery, largo Francesco Vito 1, 00168 Rome, Italy. Tel. +39 063015.4205 - 5861 - 4960. Fax +39 06 3051149. E-mail: emilymidolo@gmail.com 